\section{Utilization of indigenous practices among small ruminant farmers in controling ecto parasite in Ido local government area, Ibadan, Nigeria \\ ${ }^{* 1}$ Eniola, O., ${ }^{2}$ Shaib-Rahim, H. O., ${ }^{1}$ Ajanaku, A. O., ${ }^{1}$ Adeoye, A. S., ${ }^{1}$ Aluko, O. J. \\ ${ }^{2}$ Roberts, A. E. and ${ }^{3}$ Lawal, M. O. \\ ${ }^{1}$ Department of Agricultural Extension and Management, Federal College of Forestry, Jericho, Ibadan. \\ ${ }^{2}$ Department of Agricultural Technology, Federal College of Forestry, Ibadan. \\ ${ }^{3}$ Department of Wildlife and Ecotourism Management, Forestry Research Institute of Nigeria, Ibadan.}

Corresponding author:*larryenny2009@yahoo.co.uk+2348062411383

\begin{abstract}
High prevalence of ectoparasites in the tropics and lack of access to veterinary services necessitated the use of indigenous practices in controlling ectoparasites among small ruminant farmers. This study was carried out to assess the utilization of indigenous practices in controlling ectoparasites among small ruminant farmers in Ido Local Government Area, Ibadan, Oyo State. A multi stage sampling technique was used in selecting respondents for the study. One hundred and fifteen well-structured questionnaires were administered to the farmers and 112 were recovered from the field. Descriptive statistics such as percentage, frequency distribution and charts were used to analyse the socio-economic characteristics of the respondents. The results showed that the age 49-60 had the highest respondents (42.2\%) followed by the age group of 36-48 years (28.4\%). It also showed that majority of the respondents were female (66.7\%). Some indigenous practices highly utilized in the study area included; the application of wild lettuce (ewe yanrin) on the affected parts of the animal (97\%), Nuclea latifolin (ewe egbesi) 97\% rubbing of liquid lime (osanwewe) on the affected part (93\%). Chi Square was used to measure the relationship between respondents' selected socio-economic characteristics and their utilization. The Pearson product moment correlation (PPMC) was used to measure the relationship between respondents, constraints $(r=0.194, p=0.050)$, benefit $(r=0.201, p 0.043)$. Some of the constraints identified in the study area included inadequate useful information from extension agents, extinction of materials used and non-documentation of the leaves used while some of the benefits of the leaves includes ease of administration of the leaves, low cost of the leave, and accessibility were some of the benefit derive.
\end{abstract}

Abstract

Keywords: Indigenious practices, small ruminants, ecto-parasites, Ido local government.

\section{Introduction}

Indigenous small ruminants constitute greater percentage of ruminant population in Africa (Lebbie et al., 2004). These flocks of animals are commonly found in the rural areas where they are owned and managed under extensive system (Otchere, 2006). Small ruminants play an important role in the lives of most people especially rural farmers whose livelihood entirely depends on them. They provide source of animal protein through their meat and milk
(Fajemisin, 2001). Notwithstanding, they fetch a source of income when sold to meet some other family needs as well as play a vital social roles during ceremonies and festivals. Small ruminant management is seriously hindered by diseases in the tropics. Diseases are very important to farmers and affect the production of small ruminants in several ways. It increases cost of production, lowers production level, reduces the quality and quantity of animal products and generally causes great loss to 
the farmer. Though, proven scientific methods of preventing and managing animal diseases in form of veterinary services abound, this may not always be readily available to rural farmers who are poor and less educated. However, the rural farmers have their own local methods of preventing and managing animal diseases. Such knowledge and practices are not well documented but are passed down orally from generation to generation. There are some common diseases that affect the health of goat which include; pneumonia, mastitis, diarrhoea and mange. Although limited scientific research has focused on the use of herbal remedies in animal health care in Nigeria, many of the plants used in human medication in Nigeria are also used in ethnoveterinary practices. A number of browse plants such as Manniophyton fulvum, Microdesmis puberula, Spondiasm ombin and Aspilia africna utilized in livestock feeding have been proven to be very useful in treatment of diarrhoea, cough, snake bite, e.t.c Fern, (2014).

Ectoparasites are organisms which inhabit the skin or outgrowths of the skin of another organism (the host) for various periods, and may be detrimental to the latter. Several ectoparasites currently associated with domestic animals have been acquired by the introduction of either host or parasite into new regions, as animals have become domesticated throughout the world. For example, cattle, goats and other important domestic livestock species have been introduced into much of Africa, where they may now fall victim to the ravages of native tsetse flies (Glossina spp.) and ticks, as well as pathogens transmitted by these parasites. Relatively rapid intercontinental transportation of these animals has compounded the problem. Due to availability of indigenous practices within respondent environment, this research investigated the utilization of indigenous practices in controlling ectoparasites among small ruminant farmers in Ido local Government area of Oyo State. In doing this, the socio economic characteristics of the rural farmers, identified diseases, flock size, types and frequency of disease occurrence and the indigenous methods of preventing and managing small ruminant diseases were assessed.

\section{Methodology}

\section{Studyarea}

The study was carried out in Ido Local Government Area (LGA) of Oyo state. According to 2006 National Population Census, the total population in the Local Government was 103,261 people (National Bureau of Statistics, 2009). The people are mainly small-scale farmers with secondary occupations like hunting, trading, artisan, civil service, among others. Farmers in the area grow mainly food crops such as maize, cassava, yam, vegetables. They also engage in the cultivation of some cash crops like cocoa, kola and oil palm etc.

\section{Population of the study}

The population of the study comprises of all small ruminant farmers in Ido local government area of Oyo state Ibadan.

\section{Sampling procedure and sampling size}

This study was carried out in Ido local government area of Oyo state. A multi-stage sampling technique was used to select the respondents for this study. Ido local government area of Oyo state was purposely selected for this study due to the availability of small ruminant farmers in the local government. The first stage involved selection of three farming communities which are; Ido, Omi Adio, Bakatari. The communities were purposively selected because they constitute the centres of intensive traditional agricultural activities and some of their agricultural practices. The next stage was random selection of one hundred and fifteen (115) farmers from the chosen communities. A Structured questionnaire was administered to the 


\section{Eniola, Shaib-Rahim, Ajanaku, Adeoye, Aluko, Roberts and Lawal}

respondents.

\section{Data analysis}

Descriptive statistic such as frequency and percentage were used to analyze the socioeconomic characteristics and utilization of indigenous knowledge used by the respondents while Pearson product moment correlation (PPMC) was used to analyze the problems militating against the use of indigenous practices in controlling ectoparasites, respectively.

\section{Results and discussion \\ Socio-economic characteristics of the respondents}

The result of analysis in Table 1 shows that age groups of 49-60 years had the highest number of respondents $(42.2 \%)$, followed by the age group of $36-48$ years $(28.4 \%)$. Implication of this is that majority of the respondents are in their active age which is in line with Madhur (2000) who says age squared proxy by life cycle represent experience i.e age widen experience in business. Result of Analysis also revealed that majority of the respondents $(66.7 \%)$ were female while (33.3\%) were male, which mean utilization of indigenous practices in controlling ecto-parasite not exemption of female even though they are more involved in harvesting of farming products in the study area. This is due to the fact that women were more involved in supplementing farm income in off season periods (Larinde and Kehinde, 2003). The table also revealed that the respondents' marital status were $(74.5 \%)$ married, $(15.7 \%)$ widow and $(7.8 \%)$ single. The results also showed that $45.1 \%, 43.1 \%$ and $11.8 \%$ were Islam, Christianity and Traditional religion respectively. This implied that majority of those involved in utilization of indigenous practices in controlling ecto-parasite were Muslims and Christians. This observation is in line with
Adekunle et al. (2011) that religion practices are common in Nigeria setting, especially the christian and islamic religions. Majority $(33.3 \%)$ of the respondents had tertiary education, while $31.4 \%$ and $22.5 \%$ had no formal education and secondary education respectively. This shows that the level of education could influence their utilization of indigenous practices in controlling ecto-parasite. This also corresponds to findings of Swanson (2008) which argued that education enables farmers to make informed decision regarding adoption and managing their lives successfully to cope with everyday problem and to realize their opportunities. Result of analysis further revealed that majority of the respondents got their source of labour from family $(61.8 \%)$. Furthermore, majority of the respondents had $82.4 \%$ belongs to one farmer organization or the other, this will also broading their knowlege and ehance their understanding of a particular innovations on some indigenous practices. The results also show that majority had above 10years experience. Majority of the respondents had $<30,001-<50,000$ and $<20,001-<30,000$ with $68.6 \%$, and $13.7 \%$ respectively as their income generated in the study area.

Different herbs used by respondents and rate of their utilization

Results of analysis in Table 2 revealed that majority of the responsents in the study area $(74 \%, 72 \%, 72 \%$ and $62 \%)$ utilized lime, hand picking, bitter gourd (ejinri) and palm kernel oil respectively to remove ticks and lice from the affected parts of the animals. While $(5 \%, 21 \%, 23 \%, 23 \%)$ of them use locust beans, liquid from slim mixed with pawpaw leave liquid, vitellaria and potash and tobacco leaves extract respectively to treat ecto-parasites on their animals. Meanwhile, $28 \%$ of the respondents use Ficus leaves to control lice on the body of their animals. 
Utilization of indigenous practices among small ruminant farmers in controling ecto parasite

Table 1: Socio-economic characteristics of respondents

\begin{tabular}{|c|c|c|}
\hline Variables & Frequency & Percentage $\%$ \\
\hline \multicolumn{3}{|l|}{ Age (years) } \\
\hline $25-35$ & 23 & 22.5 \\
\hline $36-48$ & 29 & 28.4 \\
\hline $49-60$ & 43 & 42.2 \\
\hline Above 60 & 7 & 6.9 \\
\hline \multicolumn{3}{|l|}{ Sex } \\
\hline Male & 34 & 33.3 \\
\hline Female & 68 & 66.7 \\
\hline \multicolumn{3}{|l|}{ Marital status } \\
\hline Married & 76 & 74.5 \\
\hline Single & 8 & 7.8 \\
\hline Widow & 16 & 15.7 \\
\hline Divorce & 2 & 2.0 \\
\hline \multicolumn{3}{|l|}{ Religion } \\
\hline Christianity & 44 & 43.1 \\
\hline Islam & 46 & 45.1 \\
\hline Traditional & 12 & 11.8 \\
\hline \multicolumn{3}{|l|}{ Household size } \\
\hline $2-4$ & 80 & 78.4 \\
\hline $5-7$ & 1 & 1.0 \\
\hline Above 7 & 21 & 20.6 \\
\hline \multicolumn{3}{|l|}{ Education attainment } \\
\hline No formal education & 32 & 31.4 \\
\hline Adult education & 5 & 4.9 \\
\hline Primary education & 8 & 7.8 \\
\hline Secondary education & 23 & 22.5 \\
\hline Tertiary education & 34 & 33.3 \\
\hline \multicolumn{3}{|l|}{ Source of labour } \\
\hline Family & 63 & 61.8 \\
\hline Hired & 39 & 38.2 \\
\hline \multicolumn{3}{|c|}{ Membership of association } \\
\hline None & 10 & 9.8 \\
\hline Cooperative society & 8 & 7.8 \\
\hline Farmer organization & 84 & 82.4 \\
\hline \multicolumn{3}{|c|}{ Year of farming experience } \\
\hline $4-6$ & 30 & 29.4 \\
\hline $7-10$ & 35 & 34.3 \\
\hline Above 10 & 37 & 36.3 \\
\hline \multicolumn{3}{|l|}{ Income (\#) } \\
\hline $10,000-20,000$ & 9 & 8.8 \\
\hline $20,001-30,000$ & 14 & 13.7 \\
\hline $30,001-50,000$ & 70 & 68.6 \\
\hline Above 50,000 & 9 & 8.8 \\
\hline
\end{tabular}

Result of analysis in Table 4 shows constraints facing by respondents on utilization of indigenous practices in controlling ecto-parasite in the study area. Majority $(83.3 \%)$ had high constraint on size of the farm, follow by $(66.7 \%)$ had inadequate extension agent information
$(54.9 \%)$ had Most of those thing as go to extinction do to non-propagation, $(51.0 \%)$ had Repeatability of it is not possible because of non-documentation while few majorities had low constraints to illiteracy $(51.0 \%)$. 
Eniola, Shaib-Rahim, Ajanaku, Adeoye, Aluko, Roberts and Lawal

Table 2: Different herbs used by respondents and rate of their utilization

\begin{tabular}{|c|c|c|c|}
\hline 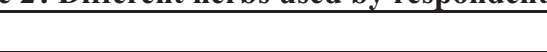 & Highly utilized & Low utilized & Not utilized \\
\hline $\begin{array}{l}\text { 1. Bitter gourd (ejinri) is use in } \\
\text { washing the affected part of the } \\
\text { animal. }\end{array}$ & $72(70.6)$ & $16(15.7)$ & $14(13.7)$ \\
\hline $\begin{array}{l}\text { 2. Squeezing tobacco leaves to extract } \\
\text { liquid to rub on the body of the } \\
\text { affected animal. }\end{array}$ & $23(22.5)$ & $58(56.9)$ & $21(20.6)$ \\
\hline $\begin{array}{l}\text { 3. Ficus leaves (ewe epin) is used in } \\
\text { controlling lice by putting it in their } \\
\text { house. }\end{array}$ & $28(27.5)$ & $51(50.0)$ & $23(22.5)$ \\
\hline $\begin{array}{l}\text { 4. Administration of the liquid from } \\
\text { slim weed (ewe akintola) mixed } \\
\text { with pawpaw leave (akoibepe) and } \\
\text { applied to the affected part of the } \\
\text { animal. }\end{array}$ & $21(20.6)$ & $54(52.9)$ & $27(26.5)$ \\
\hline $\begin{array}{l}\text { 5. Use of locust beans by rubbing it on } \\
\text { the affected part of the animal. }\end{array}$ & $5 \quad(4.9)$ & 17 (16.7) & $80(78.4)$ \\
\hline $\begin{array}{l}\text { 6. Manual removal of ectoparasite (use } \\
\text { of hand) }\end{array}$ & $72(70.6)$ & $21 \quad(20.6)$ & $(8.8)$ \\
\hline $\begin{array}{l}\text { 7. Palm kernel oil is rubbed on the } \\
\text { affected part of the animal. }\end{array}$ & $62(60.8)$ & 31 (30.4) & $(8.8)$ \\
\hline $\begin{array}{l}\text { 8. Use of herbs vitellaria used for ticks } \\
\text { and by rubbing potash on the } \\
\text { affected part of the body of the } \\
\text { animal. }\end{array}$ & $23(22.5)$ & $61 \quad(59.8)$ & $18(17.6$ \\
\hline $\begin{array}{l}\text { 9. Rubbing of liquid lime (osanwewe) } \\
\text { and also the use of palm oil on the } \\
\text { body of the animal. }\end{array}$ & $74 \quad(72.5)$ & 19 (18.6) & (8.8) \\
\hline
\end{tabular}

Table 3: Categorization of respondents' utilization

\begin{tabular}{lllllll}
\hline & F & $\%$ & mean & SD & minimum & Maximum \\
\hline High & 63 & 61.8 & 15.33 & 5.03 & 0.00 & 24.00 \\
Low & 49 & 38.2 & & & & \\
Total & 102 & 100 & & & & \\
\hline
\end{tabular}

Table 4: Constraints to indigenous practices

\begin{tabular}{|c|c|c|c|}
\hline & High Constraint & Low Constraint & $\begin{array}{l}\text { Not a } \\
\text { Constraint }\end{array}$ \\
\hline $\begin{array}{l}\text { 1. inadequate extension agents } \\
\text { information }\end{array}$ & $68(66.7)$ & $31(30.4)$ & $3 \quad(2.9)$ \\
\hline 2. overdose of local herbs & $49(48.0)$ & $50 \quad(49.0)$ & $(2.9)$ \\
\hline 3. illiteracy & $38(37.3)$ & $52(51.0)$ & $12(11.8)$ \\
\hline $\begin{array}{l}\text { 4. Repeatability of it is not possible } \\
\text { because of non-documentation }\end{array}$ & $52(51.0)$ & $44(43.1)$ & $6 \quad(5.9)$ \\
\hline $\begin{array}{l}\text { 5. Most of those thing as go to } \\
\text { extinction do to non-propagation. }\end{array}$ & $56(54.9)$ & $40(39.2)$ & $(5.9)$ \\
\hline 6. Size of the farm & $85(83.3)$ & $14(13.7)$ & $(2.0)$ \\
\hline
\end{tabular}

Table 5: Categorization of respondents' constraints

\begin{tabular}{lllllll}
\hline & F & $\%$ & Mean & SD & minimum & maximum \\
\hline High & 69 & 67.6 & 9.09 & 1.79 & 4.00 & 12.00 \\
Low & 33 & 32.4 & & & & \\
Total & 102 & 100 & & & & \\
\hline
\end{tabular}


Result of analysis in Table 6 shows the benefits derived by respondents on utilization of indigenous practices in controlling ecto-parasite in the study area. Majority (70.6\%) enjoys indigenous practices as a way of removing of chemical residue from the body of animal to a large extent while majority $(48.0 \%, 47.1 \%$ and $46.1 \%$ ) of the respondents see it as cheaper compared to veterinary drugs, easily accessible and affordable respectively on lesser extent in the study area.

Table 6: Benefits derived by respondents from the use of indigenous knowledge to control ectoparasites by ruminant farmers

\begin{tabular}{|c|c|c|c|c|}
\hline & Large extent & Lesser extent & Rarely & Not extent \\
\hline $\begin{array}{l}\text { 1. it helps to remove effect } \\
\text { of chemical residue. }\end{array}$ & $72(70.6)$ & $14 \quad(13.7)$ & $\begin{array}{ll}15 & (14.7)\end{array}$ & $\begin{array}{ll}1 & (1.0)\end{array}$ \\
\hline $\begin{array}{l}\text { 2. it is cheaper compared to } \\
\text { veterinary drugs }\end{array}$ & $36 \quad(35.3)$ & $(48.0)$ & $(15.7)$ & $1(1.0)$ \\
\hline 3. very easy to administer & $47(46.1)$ & $(33.3)$ & $(18.6)$ & $(2.0)$ \\
\hline 4. it is affordable & $35 \quad(34.3)$ & $(46.1)$ & $(18.6)$ & $(1.0)$ \\
\hline 5. it is easily accessible & $23(22.5)$ & $(47.1)$ & (28.4) & (2.0) \\
\hline 6. it is readily available & $20(19.6)$ & (32.4) & $(44.1)$ & (3.9) \\
\hline
\end{tabular}

Table 7: Categorization of respondents' benefits derived by respondents from the use of indigenous knowledge to control ectoparasites by ruminant farmers

\begin{tabular}{lllllll}
\hline & F & $\%$ & mean & SD & minimum & maximum \\
\hline High & 70 & 68.6 & 12.67 & 3.19 & 0.00 & 18.00 \\
Low & 32 & 31.4 & & & & \\
Total & 102 & 100 & & & & \\
\hline
\end{tabular}

\section{Chi-square relationship between} respondents selected socio-economic characteristics and their utilization

The result of analysis in Table 8 , revealed that there was no significant relationship between respondents selected socioeconomic characteristics and their utilization. This result implies that results of utilization of indigenous practices in the study area is not a function of sex, age, marital status, religion, household size, level of education, source of labour, membership of association, year of farming experience and income which connotes that all selected socio-economic characteristics are not determinants of utilization of indigenous practices among small ruminant farmers in controlling ectoparasite in the study area.

Table 8: Chi-square analysis

\begin{tabular}{llll}
\hline Variables & $\mathrm{X}^{2}$-value & $\mathrm{p}$-value & Decision \\
\hline Age & 15.150 & 0.233 & $\mathrm{NS}$ \\
Sex & 8.209 & 0.084 & $\mathrm{NS}$ \\
Marital Status & 9.515 & 0.658 & $\mathrm{NS}$ \\
Religion & 2.270 & 0.972 & $\mathrm{NS}$ \\
Household size & 10.335 & 0.242 & $\mathrm{NS}$ \\
Level of Education & 17.468 & 0.356 & $\mathrm{NS}$ \\
Source of labour & 5.327 & 0.255 & $\mathrm{NS}$ \\
Membership of Association & 15.184 & 0.056 & $\mathrm{NS}$ \\
Year of farming experience & 8.068 & 0.427 & $\mathrm{NS}$ \\
Income & 14.105 & 0.294 & $\mathrm{NS}$ \\
\hline
\end{tabular}


Eniola, Shaib-Rahim, Ajanaku, Adeoye, Aluko, Roberts and Lawal

Relationship between respondents' constraint, benefit and their utilization

Results of analysis in Table 9 revealed that constraint $(r=0.194, p=0.050)$, benefit $(r=$ $0.201, p=0.043)$ of respondents has significant relationship with their

Table 9: PPMC analysis of relationship between utilization

\begin{tabular}{llll}
\hline Variable & r-value & p-value & Decision \\
\hline Constraint & 0.194 & 0.050 & $\mathrm{~S}$ \\
Benefit & 0.201 & 0.043 & $\mathrm{~S}$ \\
\hline
\end{tabular}

\section{Conclusion}

This study revealed that farmers in the study area were predominantly females and were muslims who are married and are in their youthful age. It can be deduced from the study that majority of the respondents have been using these indigenious practices in controling ecto-parasites in ruminant animals for over 10 years. Furthermore, it was revealed that majority of them use lime, bitter gourd (ejinrin), hand picking and palm kernel oil to remove ectoparasites from the body of their animals while a few of them use locust bean, liquid from slim weed mixed with pawpaw leaves extract, vitellaria and potash. However, some also uses Ficus leaves (ewe epin) to control lice. The facts that these resources are available within their reach at no cost and the farmers are awaere of their usefulness make their utilization easier for the farmers.

\section{References}

Adekunle, M. F., Oloruntobe, A., Ajibola, A. A. and Agbaje, B. M. 2011. Contribution of Non-Wood Forest Products (NWFP) to Livelihood Generation Products in Eriti Community Forest Wetlands, Ogun State, Nigeria.

Chah, J., Igbokwe, E., and Chah, K. 2009. Ethnoveterinary medicine used in small ruminant health in the Eastern Guinea Sava nna, Nigeria. Livestock Research for Rural utilization. This result implies that constraint and benefit are determinants of utilization of indigenous practices among small ruminant farmers in controlling ectoparasite in the study area.

respondents' constraint, benefits and their
Development, 21 (12). [4]. F A O S T A T ( $\left.\begin{array}{llll}2 & 0 & 0 & 9\end{array}\right)$, http://faostat.fao.org/default.aspx

Fajeminsin, B. A. 2001 "Goat milk production". In: National Animal Production and Research Institute Proceedings, Institutes Seminar, 113.

Fern, K. 2014. Useful tropical plants. www. https//Tropical.theferns.info

Lebbie, S. H. B., Rey, B. and Irungu, E. K. 2004. Small Ruminant Research and Development in Africa: Proceedings of the Second Biennial Conference of the African Small Ruminant Research Network: AICC, Arusha, Tanzania, 7-11 December 1992: International Livestock Centre for Africa.

Larinde, S. L. and Kehinde, A. L. 2003. Gender determinant of farm income by rural dweller in Communities around depleted Onigambari Forest Reserve in Oyo State, Nigeria. Proceedings 11th Annual Conference Environment and Behavioural Association, $\mathrm{Pp}$ 369-374.

Madhur, H. 2000. Information and Communication technologies for rural development and food security; Lesson from field experience in developing countries. Pp 23-37.

Otchere, E. O. 2006. Small ruminant 
Utilization of indigenous practices among small ruminant farmers in controling ecto parasite

production in tropical Africa. FAO

Animal Production and Health

Paper(FAO), no. 58, 203- 210

Received: $20^{\text {th }}$ June, 2020

Accepted: $30^{\text {th }}$ September, 2020 